\title{
The role of gas-fluidisation in the formation of massive volcaniclastic kimberlite
}

\author{
T. M. Gernon ${ }^{1}$, R. S. J. Sparks ${ }^{1}$, M. A. Gilbertson ${ }^{2}$ \& M. Field ${ }^{1}$ \\ ${ }^{1}$ Department of Earth Sciences, University of Bristol, Bristol, BS8 1RJ, UK \\ ${ }^{2}$ Department of Mechanical Engineering, University of Bristol, Bristol, BS8 1TR, UK
}

\begin{abstract}
Massive volcaniclastic kimberlite (MVK) deposits exposed throughout the Venetia K01 Pipe (South Africa), are characterised by their uniform texture and homogeneous composition. The deposits fill $\sim 80$ vol.\% of the exposed pipe. Previous studies suggest that MVK exhibits little appreciable internal variation. However, new field results show that MVK displays significant changes over short distances (metres). The textural characteristics and large- and small-scale structure of the deposits are interpreted as due to gasfluidisation. Laboratory experiments demonstrate how tapered fluidised beds are heterogeneous, with fluidisation and mixing limited to the centre of the bed. Marginal wedge-shaped regions remain unfluidised. The unfluidised regions are internally laminated and slip downwards when a critical proportion of the bed is fluidised $(\sim 90 \%)$. The observations also demonstrate how fluctuations in gas velocity can produce steep internal boundaries between laminated and well-mixed regions.

Evidence for gas-fluidisation in MVK deposits includes the massive structure, uniform distribution of lithic clasts, presence of steep internal contacts, dominantly sub-vertical crystal fabrics across the vent, occurrence of surface-derived material along the tapered pipe walls, and the presence of degassing structures. We propose that the overall structure is consistent with a multi-stage fluidised emplacement, which involved (1) strong initial fluidisation that caused thorough mixing of juvenile and lithic material; (2) a gradual step-wise decrease in gas flux, that produced nested pipe-like sequences; and (3) migration of the narrow fluidised column towards the steep eastern pipe wall. The superimposition of (4) isolated degassing structures on the statistically massive deposits across the vent is consistent with an overall rapid gas withdrawal from the system at the end of the eruption.
\end{abstract}

\section{Introduction}

Fluidisation is commonly invoked as an important process during the formation of volcaniclastic deposits infilling diatremes. Here, diatremes are defined as volcanic pipes or vents filled with clastogenic mixtures of pyroclastic and country rock material, and believed to form by gas-rich volcanic eruptions (Cloos, 1941; Hearn, 1968). Fluidisation occurs when particles become fully suspended in a gas flow and assume a liquid-like state. Diatremes are a favourable environment to develop fluidised systems since they tend to back fill with pyroclastic material, and magmas supply gas or gas-particle flows through the deposits.

The concept of fluidisation was introduced to geology by Reynolds (1954) to describe the transport of solid particles by high velocity gas flows. Fluidisation has since been identified as a major process in the emplacement of pyroclastic flows (Sparks, 1976; Wilson, 1980; Druitt, 1995).

Fluidisation and related processes (e.g. gastuff fluxing) have long been invoked to account for geological features observed in diatremes (e.g. Geikie, 1902; Cloos, 1941; Dawson, 1962, 1971; Hearn 1968; Mitchell, 1986; Sparks et al., 2006). The concept of fluidisation has been applied to the formation of ventfill deposits in kimberlites (Dawson, 1962; Dawson, 1971; Woolsey et al., 1975; McCallum et al., 1976; Clement, 1982; Walters et al., 2006; Sparks et al., 2006; Gernon, 2007). Although it has been widely accepted that fluidisation plays some role in the formation of kimberlite pipe-fills, there is considerable divergence in opinion over the context and degree to which it occurs.

The purpose of this paper is to present geological data from the Venetia K01 Pipe (South Africa), which contains massive volcaniclastic kimberlite (MVK) deposits. Fluidisation has previously been invoked in the formation of this distinctive lithofacies (Sparks et al., 2006; Walters et al., 2006). Laboratory experiments on the gas-fluidisation behaviour of particles in tapered rigid containers provide new insights into the processes that formed MVK deposits.

\section{Fluidisation}

Here, we use fluidisation as a term that describes the response of a bed of particles to an upward flow of interstitial gas (see Sparks et al., 2006). Fluidisation is the state attained when the upward drag force exerted by a gas exceeds the weight of particles in a bed (Davidson and Harrison, 1963). The superficial gas velocity $\left(\mathrm{U}_{\mathrm{g}}\right)$ at which a granular bed becomes fluidised is known as the minimum fluidisation velocity, $\mathrm{U}_{\mathrm{mf}}$ (Ergun, 1952; Davidson and Harrison, 1963). If the superficial gas velocity exceeds the freefall velocity of individual particles, they are generally removed or elutriated from the system. Gas bubbles are 
the main agent of mixing in fluidised beds, and generally occur when $U_{g}>U_{m f}$.

\section{Field observations (Venetia K01, SA)}

The Venetia K01 Pipe is dominated by MVK deposits (Walters et al., 2006; Gernon, 2007). MVK has a typically structureless appearance (Fig. 1a), and dominantly comprises olivine crystal fragments and sub-rounded olivine megacrysts (25-40 vol.\%), and a polymict range of lithic clasts $(\sim 10-30$ vol.\%). The olivine crystals have been entirely replaced by serpentine. Kimberlite-related crystal components also include garnet, ilmenite, phlogopite, spinel, perovskite, andradite and rutile. An important feature of the deposits is the predominance of sub-vertical fabrics defined by the alignment of elongate olivine crystals.

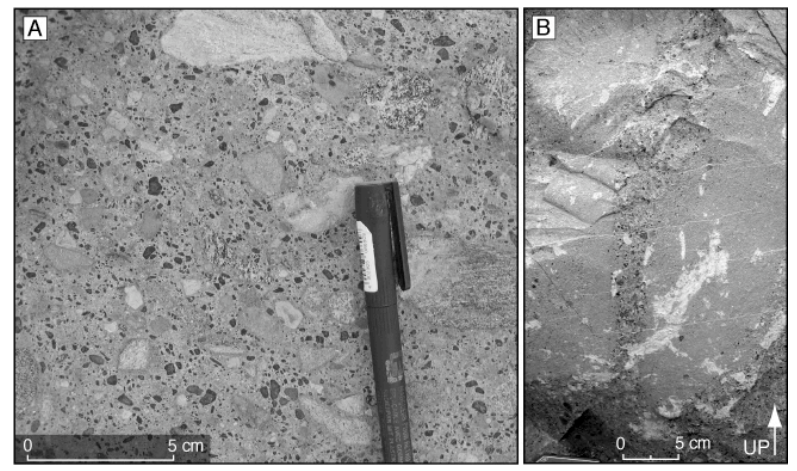

Figure 1: (A) Typical field exposure of MVK showing lithic clasts and dark sub-rounded olivine megacrysts in a matrix of small serpentinised olivine crystals. (B) Well-developed degassing structure from K01. The structures contain small lithic clasts $(<1 \mathrm{~cm})$ and coarse crystals, and are significantly coarser-grained than their host tuffs.

The interstices between olivine crystals are occupied dominantly by secondary diopside-serpentine cements $(30-45 \%)$, with sub-ordinate talc, lizardite, smectite, brucite and chlorite (Stripp et al., 2006). The void-filling assemblages are indicative of a hot original deposit $\left(>400^{\circ} \mathrm{C}\right)$ with $\sim 30-45 \%$ porosity (Stripp et al., 2006). A conspicuous feature of the deposits is the presence of 5-6 steep internal contacts, which separate massive volcaniclastic units of slightly different grainsize and lithic composition. The western-most unit adjacent to the tapered pipe wall consists of bedded strata containing surface-derived mudstone.

Though the overall characteristics of MVK are uniform both in terms of texture (Fig. 1a) and lithic distributions, several departures from homogeneity are recognised across the pipe. These include the occurrence of: (1) degassing structures (Fig. 1b; Gernon et al., 2008a), (2) "patchy" fines-rich regions exhibiting irregular geometries, (3) lithic concentration zones, and (4) fines-rich pipe-like structures, developed above lithic clasts. These are commonly localised features, developed on a 1-10 metre scale. They commonly grade laterally and vertically into more typical MVK.

\section{Laboratory experiments}

We performed a series of laboratory experiments to determine the gas-fluidisation behaviour of particles in both confined straight-sided and tapered containers, as an analogue to volcaniclastic materials infilling a kimberlite pipe, in the presence of a gas flow (see Gernon et al., 2008b). We show that beds in straightsided containers become homogeneously fluidised, whereas beds in tapered containers become heterogeneous, with fluidisation limited to a central roughly hyperboloid-shaped region (Fig. 2). This region can be divided into two zones: (1) a zone occupied by bubbles and a net upward movement of particles, and (2) a zone where particles are fluidised, but form a downward return flow. Marginal laminated regions remain unfluidised (Fig. 2), and slip downwards when a critical proportion of the bed is fluidised - generating a "conveyor-belt" mechanism of particle transport. The width of the central fluidised region increases with increasing gas flux, producing steep internal boundaries between fluidised and unfluidised particles (Fig. 2).

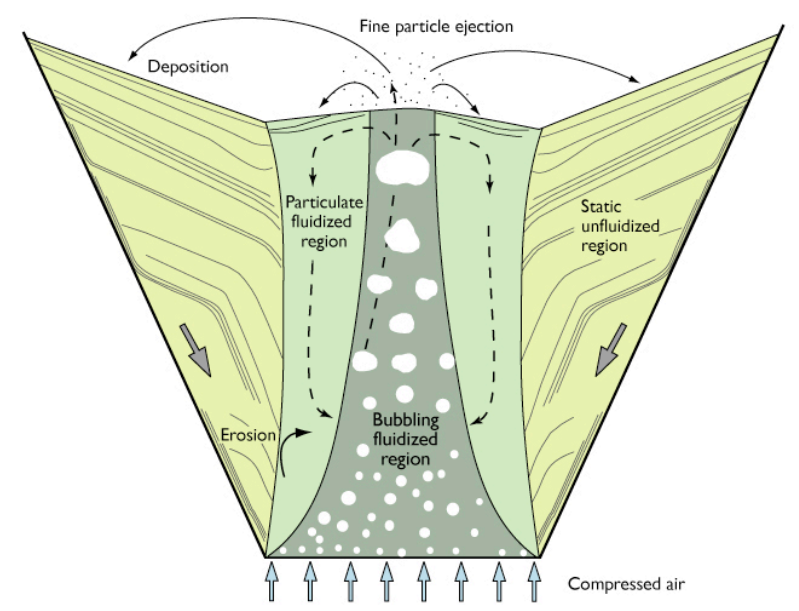

Figure 2: Schematic diagram of the behaviour of a tapered fluidised bed (see text; modified from Gernon et al., 2008b).

\section{Discussion}

At the Venetia K01 Pipe, the (1) uniform distribution of lithic clasts; (2) homogeneous appearance; (3) steep internal contacts; (4) presence of degassing structures (similar to elutriation pipes in ignimbrites; see Gernon et al., 2008a), and (5) paucity of fines (Stripp et al., 2006) in the MVK deposits, can be explained by gasfluidisation of the pipe-fill. Sparks et al. (2006) and Walters et al. (2006) have stressed the importance of gas-fluidisation in accounting for the well-mixed appearance of MVK. Lower limits on the temperature of the deposits of order $350-400^{\circ} \mathrm{C}$, are given by the diopside-serpentine assemblage, which precipitated in the hot pipe-fill during hydrothermal metamorphism as the pipe cooled (Stripp et al., 2006).

The sub-vertical crystal fabrics can be explained by strong vertical "streaming" of gas through the deposits, which caused crystals to align themselves 
parallel to the flow. The "patchy" fines-rich regions can also be explained by fluidisation, and are interpreted as local heterogeneities generated by the passage of bubbles during mixing. Analogous meso-scale variability with streaky fines-rich zones is reproduced in the laboratory during vigourous mixing of binary particle mixtures (Gernon, 2007).

Steep internal contacts within the K01 deposits are interpreted as primary features, developed within the pipe-fill on a syn-depositional basis. The structures juxtapose massive units of slightly different compositional and textural characteristics. The mechanism envisaged for the development of the steep internal contacts is analogous to that proposed by Walters et al. (2006) and Gernon et al. (2008b) during gas-fluidisation. When gas is supplied to a bed of particles at high gas flow-rates, an upwardly diverging thoroughly mixed "pipe" is produced. A step-wise decrease in gas flow-rate results in a nested "pipeswithin-pipes" structure. The angle of the contacts between these "pipes" may provide a constraint on the approximate degree of fluidisation within the vent (Walters et al., 2006; Gernon, 2007).

The presence of surface-derived mudstone near the margins of the pipe can be explained by the "conveyor belt" subsidence observed in experiments and resulting from vigourous fluidisation in the centre of the conduit.

\section{Conclusions}

The structure of the Venetia K01 pipe-fill, with a "nested" sequence of MVK units is interpreted as due to gas-fluidisation. During the early stages of the eruption, a homogeneous gas-particle dispersion developed across the pipe, producing a uniform distribution of lithic clasts. Our experimental observations demonstrate how fluctuations in gas velocity could have produced steep internal boundaries between laminated and well-mixed regions, and how marginal inward dipping layered sequences could have slipped into deep parts of the K01 pipe. The structure of the pipe-fill is consistent with a multi-stage fluidised emplacement, which may have involved several distinct eruptive phases of decreasing intensity. In the final stages, the gas flux shut down rapidly, with the effect of preserving the earlier formed well-mixed configuration. After the eruption, residual gas percolated through the pipe-fill, locally producing degassing structures.

\section{References}

Cloos, H., 1941. Bau und Tätigkeit von Tuffschloten. Geologische Rundschau, 32, 709-800.

Clement, C.R., 1982. A comparative geological study of some major kimberlite pipes in northern Cape and Orange Free State. Ph.D. thesis, University of Cape Town.

Davidson, J.F., Harrison, D., 1963. Fluidised Particles. Cambridge University Press.
Dawson, J.B., 1962. Basutoland kimberlites. Geological Society of America Bulletin, 73, 545-560.

Dawson, J.B., 1971. Advances in kimberlite geology. Earth Science Review, 7, 187-214.

Druitt, T.H., 1995. Settling behaviour of concentrated dispersions and some volcanological applications. Journal of Volcanology and Geothermal Research, 65, 27-39.

Ergun, S., 1952. Fluid flow through packed columns. Chemical Engineering Progress, 48 (2), 89-94.

Geikie, A., 1902. The Geology of Eastern Fife. Mem. Geol. Surv. U. K. (Scotland).

Gernon, T.M., 2007. Fluidisation and emplacement processes in kimberlite eruptions. PhD. thesis, University of Bristol.

Gernon, T.M., Field, M., Sparks, R.S.J. 2008a., Degassing structures in volcaniclastic kimberlite: Examples from southern African kimberlite pipes. Journal of Volcanology and Geothermal Research, in press.

Gernon, T.M., Gilbertson, M.A., Sparks, R.S.J., Field, M., 2008b. Gas-fluidisation in an experimental tapered bed: Insights into processes in diverging volcanic conduits. Journal of Volcanology and Geothermal Research, in press.

Hearn, B.C., 1968. Diatremes with kimberlitic affinities in north-central Montana. Science, 159, 622-625.

Mitchell, R.H., 1986. Kimberlites: Mineralogy, Geochemistry, and Petrology. Plenum Press.

Reynolds, D.L., 1954. Fluidization as a geological process, and its bearing on the problem of intrusive granites. American Journal of Science, 252, 577- 613.

Sparks, R.S.J., 1976. Grain-size variations in ignimbrites and implications for the transport of pyroclastic flows. Sedimentology, 23, 147-188.

Sparks, R.S.J., Baker, L., Brown, R.J., Field, M., Schumacher, J., Stripp, G., Walters, A., 2006. Dynamical constraints on kimberlite volcanism. Journal of Volcanology and Geothermal Research, 155, 18-48.

Stripp, G.R., Field, M., Schumacher, J.C., Sparks, R.S.J., Cressey, G., 2006. Post emplacement serpentinization and related hydrothermal metamorphism in a kimberlite from Venetia, South Africa. Journal of Metamorphic Geology, 24, $515-534$.

Walters, A. L., Phillips, J. C., Brown, R. J., Field, M., Gernon, T., Stripp, G., Sparks, R. S. J., 2006. The role of fluidisation in the formation of volcaniclastic kimberlite: grain size observations and experimental investigation. Journal of Volcanology and Geothermal Research, 155, 119-137

Woolsey, T.S., McCallum, M.E., Schumm, S.A., 1975. Modeling of diatreme emplacement by fluidization. Physics and Chemistry of the Earth, 9, 24-42.

Wilson, C.J.N., 1980. The role of fluidisation in the emplacement of pyroclastic flows: an experimental approach. Journal of Volcanology and Geothermal Research, 8, 231-249. 